\title{
MONITORING LOGAM BERAT DALAM IKAN LAUT DAN AIR TAWAR DAN EVALUASI NUTRISI DARI KONSUMSI IKAN
}

\section{MONITORING OF HEAVY METALS IN MARINE AND FRESHWATER FISHES AND NUTRITIONAL EVALUATION OF FISH CONSUMPTION}

\author{
Th. Rina Mulyaningsih \\ Pusat Teknologi Bahan Industri Nuklir, BATAN \\ Kawasan Puspiptek, Serpong 15314, \\ e-mail : thrinam@batan.go.id
}

Diterima 3 Juni 2013, diterima dalam bentuk perbaikan 18 Juli 2013, disetujui 25 Juli 2013

\begin{abstract}
ABSTRAK
MONITORING LOGAM BERAT DALAM IKAN LAUT DAN AIR TAWAR DAN EVALUASI NUTRISI DARI KONSUMSI IKAN. Ikan adalah bahan makanan sumber mineral. Serapan logam berat pada ikan dapat berasal dari air, sedimen maupun pakan ikan. Telah dilakukan monitoring mineral dan kontaminan dalam ikan untuk evaluasi nutrisi dan keamanan panqan, menqqunakan teknik analisis aktivasi neutron. Jenis ikan laut dianalisis adalah ikan kembung (Rastrelliqer fauqhni ) ikan tonakol (Acanthocybium solandri), ikan tenqiri (Authis thazard) dan ikan air tawar adalah ikan nila (Oreochromis niloticus), ikan mas (Cyprinus carpio), ikan bawal (Colossoma macropomum), yang disampling dari 6 pasar di Jakarta Utara. Hasil monitoring menunjukkan bahwa, mineral esensial yang terkandung dalam ikan adalah $\mathrm{Fe}, \mathrm{K}, \mathrm{Na}, \mathrm{Zn}, \mathrm{Ca}, \mathrm{Mg}$, dan Se. Konsentrasi Ca dan Se dalam ikan air lautlebih tinggi dibandingkan dalam ikan air tawar. Konsentrasi unsur esensial lainnya bervariasi tergantung jenis ikan. Konsentrasi logam berat As dalam ikan laut 3 kali lebih tinggi dari ikan air tawar. Logam $\mathrm{Hg}$ dan $\mathrm{Cr}$ terdeteksi dalam semua jenis ikan diamati. Dari evaluasi kecukupan nutrisi, dengan asumsi konsumsi ikan 86,68 gr/hari, untuk laki-laki umur 19 - 30 tahun, dan mengacu data dari Institute of Medicine USA, maka asupan Ca : 2,5 - 6,3; $\mathrm{Cl}:$ 1,5 - 3,3; $\mathrm{Fe}: 11,5$ - 26,9; $\mathrm{Na}: 1,5$ - 4,1; $\mathrm{K}: 3,4$ - 6,7 dan Zn 3,9 - 7,2 \% dari nilai yang direkomendasikan. Asupan $\mathrm{Cr}$ melebihi dari nilai yang direkomendasikan, sedangkan As dan $\mathrm{Hg}$ tidak direkomendasikan ada dalam bahan pangan. Pada kenyataannya logam tersebut terkandung di dalam ikan diteliti, tetapi konsentrasinya masih di bawah nilai baku mutu yang dikeluarkan oleh BPOM.
\end{abstract}

Kata kunci : ikan laut, ikan air tawar, nutrisi, mineral, logam berat

\section{ABSTRACT}

MONITORING OF HEAVY METALS IN MARINE AND FRESHWATER FISHES AND NUTRITIONAL EVALUATION OF FISH CONSUMPTION. Fish is a food source of minerals. Uptake of heavy metals in fish could come from water, sediment and fish feed. Monitoring of minerals content and contaminants in fish has been carried out to evaluate nutrition and food safetv, usina neutron activation analvsistechniques. Marine fish species that being analyzed are kembung (Rastrelliger faughni), mackerel (Acanthocybium solandri), tuna (Authis thazard) and freshwater fishes are bawal (Colossoma macropomum), nila (Oreochromisniloticus), mas (Cyprinus carpio), sampled from 6 markets in North Jakarta. Monitoring results indicate that the essential minerals contained in fish are $\mathrm{Fe}, \mathrm{K}, \mathrm{Na}, \mathrm{Zn}, \mathrm{Ca}, \mathrm{Mg}$, and Se. Se and Ca concentrations in marine fish are higher than in freshwater fish. The concentration of other essential elements varies depending on the type of fish. The concentration of arsenic in marine fish is 3 times higher than that of freshwater fish; $\mathrm{Hg}$ and $\mathrm{Cr}$ content in all fish species were observed. From the evaluation of the adequacy of nutrition, with assuming a consumption of 86.68 $\mathrm{g}$ fish/day, for men aged 19 - 30 years, and referring to data from the Institute of Medicine USA, the Ca intake : 2.5 - 6.3; $\mathrm{Cl}: 1.5$ - 3.3; $\mathrm{Fe}: 11.5$ - 26.9; $\mathrm{Na}: 1.5$ - 4.1; $\mathrm{K}: 3.4$ - 6.7 and $\mathrm{Zn} 3.9$ - 7.2\% of the recommended value. Cr intake exceeds the recommended value, while As and $\mathrm{Hg}$ is not recommended in the food. In fact these metals contained in the studied fish, but the concentration is still below the value of standards issued by BPOM.

Key words : marine fish, fresh water fish, nutrition, mineral, heavy metals

\section{PENDAHULUAN}

Indonesia sebagai negara maritim memiliki sumberdaya perikanan yang sangat besar. Berdasarkan laporan di FAO (Food and Agriculture Organization) tingkatkonsumsi ikan perkapita masyarakat Indonesia masih rendah 
bila dibandingkan dengan Malaysia 55,4 kg/kapita dan Singapura 37,9 kg/kapita. Menurut data yang diambil dari WPI KKP(1), tingkat konsumsi ikan masyarakat Indonesia selama lima tahun terakhir dari 2007 - 2011 adalah, pada 2007 (26 kg/kap/thn), 2008 (28 kg/kap/thn), 2009 (29,08 kg/kap/thn), 2010 (30,48 kg/kap/thn), dan 2011 (31,64 kg/kap/thn). Mengalami kenaikan rata-rata sebesar 5,06 \%.

Ikan merupakan salah satu bahan makanan vana menaanduna berbaqai macam zat nutrisi. seperti asam lemak tak ienuh, vodium, selenium, flourida, zat besi, magnesium, dan żnk. Dari beberapa penelitian sebelumnva diketahui bahwa ikan menqandung logam berat seperti $\mathrm{Pb}, \mathrm{Cu}, \mathrm{Ha}, \mathrm{Cr}(2,3,4,5)$. Serapan logam berat oleh ikan dapat melalui air, pakan dan sedimen, sehinqqa kontaminasi pada ikan dapat disebabkan karena adanya pencemaran pada lingkungan perairan maupun pakan ikan.

Dari beberapa penelitian menuniukkan dengan adanva peningkatan kegiatan manusia berdampak terhadap penurunan kualitas perairan $(2,5,6)$. Loaam berat dari komponen linakunaan akan menaalami biomagnifikasi dan melalui rantai makanan akhirnva akan berdampak terhadap kesehatan manusia. Jenis ikan vang dikonsumsi oleh masyarakat Indonesia tidak hanya ikan laut, tetapi juga ikan air tawar yang saat ini banyak dibudidavakan. Berdasarkan data vang ada, ienis ikan vang banvak dikonsumsi oleh masvarakat adalah ikan kembuna (Rastrelliger faughni ) 7,87 \%, ikan nila (Oreochromis niloticus) 7,17\%, ikan tongkol (Acanthocvbium solandri) $5,55 \%$, ikan tengiri (Authis thazard) 5,1 \%, ikan mas (Cyprinus carpio) 4,96 \% dan ikan bawal (Colossoma macropomum) (7).

Sebaqai bahan makanan vang kava akan mineral dan mudah didapat di Indonesia, maka kualitas bahan makanan ini perlu diiaqa. Untuk itu, dilakukan monitoring untuk tuiuan keamanan panqan dan penelitian nutrisi perlu dilakukan. Kadar mineral maupun kontaminan logam berat dalam ikan biasanva dalam level vang cukup rendah, sehinqqa diperlukan teknik analisis vang memiliki kepekaan tinqqi. Teknik analisis aktivasi neutron adalah teknik analisis vana memiliki tinakat akurasi. presisi bagus dan level deteksi unsur hingga orde ppb, sehingga teknik ini tepat digunakan untuk kegiatan ini (8).

Pada penelitian ini telah dilakukan analisis mineral dan kontaminan logam berat di dalam daging ikan vana biasa dikonsumsi oleh masvarakat. Dari keqiatan diharapkan dapat diperoleh data mineral essensial terkandung dalam berbagai ienis ikan sehinqqa masvarakat terpacu untuk mengkonsumsinva, dan sekaliqus menqetahui kontaminan logam berat vang mungkin terkandung dalam ikan vang seharusnva tidak boleh ada karena bersifat toksik. Data-data vana diperoleh dapat diaunakan untuk menaevaluasi asuban nutrisi vana diterima konsumen dan untuk informasi keamanan pangan, sehingga kepedulian terhadap kualitas bahan pangan meningkat.

\section{METODOLOGI}

\section{Pengambilan Cuplikan}

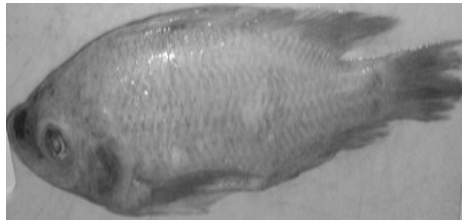

Ikan Nila (Oreochromis niloticus)

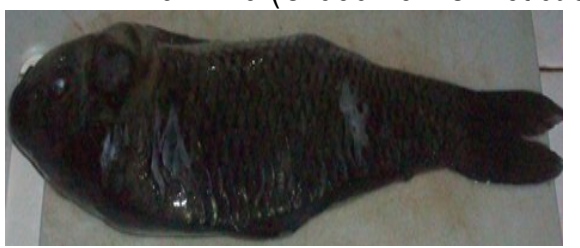

Ikan Mas(Cyprinus carpio)

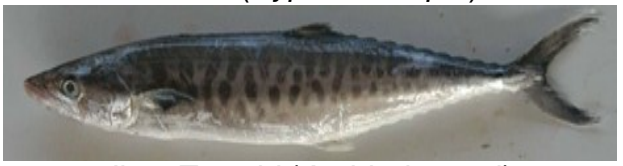

Ikan Tengiri (Authisthazard)

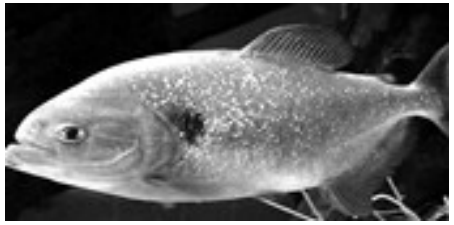

Ikan Bawal (Colossoma macropomum

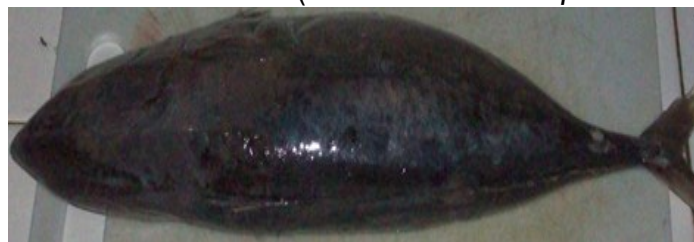

Ikan Tongkol (Acanthocybium solandri)

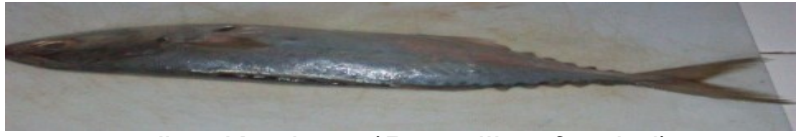

Ikan Kembung (Rastrelligerfaughni)

Gambar 1. Jenis-jenis ikan yang diteliti 
Cuplikan ikan (vang banvak dikonsumsi oleh masvarakat) diperoleh denqan cara membeli di 5 Pasar tradisionil vana ada di Jakarta Utara vaitu dari Pasar Koia, Pasar Tuqu, Pasar Lontar, Pasar Kaget dan Pasar Kompleks. Penqambilan cuplikan dilakukan secara random, masinq-masing 6 ienis ikan (3 ienis ikan laut dan 3 jenis ikan air tawar), vaitu ikan tongkol, ikan kembung, ikan tengiri, ikan nila, ikan mas dan ikan bawal. Berikut merupakan gambar jenis ikan yang dicuplik pada penelitian ini.

\section{Preparasi dan Iradiasi Dengan Neutron Thermal}

Ikan hasil pencuplikan dimasukkan dalam kantong plastik klip, di laboratorium dicuci denqan air kran. Masinq-masing ikan diambil daqingnva, dicuci denqan aquabidest dan ditiriskan, daginq dihancurkan denqan cara ditekan-tekan dalam kantung plastik klip, ditimbanq untuk mendapatkan berat basah, dibekukan dalam freezer selama 24 iam dan dikerinakan denaan freeze drier pada suhu $-60{ }^{\circ} \mathrm{C}$ selama 72 iam. Cuplikan ikan vana sudah kering kembali ditimbanq untuk mendapatkan berat kerinq, kemudian dihaluskan denqan ditumbuk menggunakan mortar agate hingga diperoleh butiran halus dan diayak dengan ayakan 200 mesh.

Cuplikan halus ditem patkan dalam vial 0,3 ml dan ditimbang denqan menqqunakan neraca mikro 30 - 70 ma. Disiapkan masinq-masing tiga kali penqulangan penimbanqan tiap cuplikan untuk analisis nuklida denqan waktu paro pendek (orde menit-iam), medium (orde hari), panjang (orde bulan-tahun). Iradiasi dan pencacahan dilakukan dengan kondisi seperti tercantum dalam Tabel 1.

Tabel 1. Skema iradiasi dan pencacahan cuplikan ikan

\begin{tabular}{cclll}
\hline $\begin{array}{c}\text { Fluks neutron } \\
\mathrm{n} / \mathrm{cm}^{2} . \mathrm{dt}\end{array}$ & \multicolumn{1}{c}{$\mathrm{T}_{\mathrm{i}}$} & \multicolumn{1}{c}{$\mathrm{T}_{\mathrm{d}}$} & \multicolumn{1}{c}{$\mathrm{T}_{\mathrm{c}}$} & \multicolumn{1}{c}{ Unsur ditentukan } \\
\hline$\sim 3.10^{13}$ & 1-2 menit & 3-5 menit & 200 detik & $\mathrm{Na}, \mathrm{Mg}, \mathrm{Ca}, \mathrm{Mn}, \mathrm{Cl}$ \\
& 60 menit & 10-15 menit & $\mathrm{K}, \mathrm{Na}, \mathrm{Mn}$ \\
& 15 menit & 2-3 hari & $30-60$ menit & $\mathrm{K}, \mathrm{Br}, \mathrm{La}, \mathrm{Rb}, \mathrm{As}, \mathrm{Cd}$ \\
& 4 jam & 7-10 hari & $60-120$ menit & $\mathrm{Fe}, \mathrm{Hg}, \mathrm{Se}, \mathrm{Co}, \mathrm{Zn}, \mathrm{Sb}, \mathrm{Cr}$ \\
\hline
\end{tabular}

Iradiasi dilakukan di Fasilitas Iradiasi System Rabbit Reaktor Serba Guna GA Siwabessy Serponq. Pencacahan tarqet pasca iradiasi menqqunakan Spektrometer Gamma vanq dilenqkapi denqan detektor aermanium kemurnian tinaai (HPGe) dari Canberra denaan efisiensi $30 \%$. resolusi $1.8 \mathrm{keV}$ pada enerai aamma 1332,50 keV dari Co-60. Penqolahan data menqqunakan perangkat lunak Hypermet dan ko-IAEA. Untuk penqendalian mutu internal hasil pengujian digunakan bahan standar acuan dari NIST : SRM 1566b Oyster tissue.

\section{HASIL DAN PEMBAHASAN}

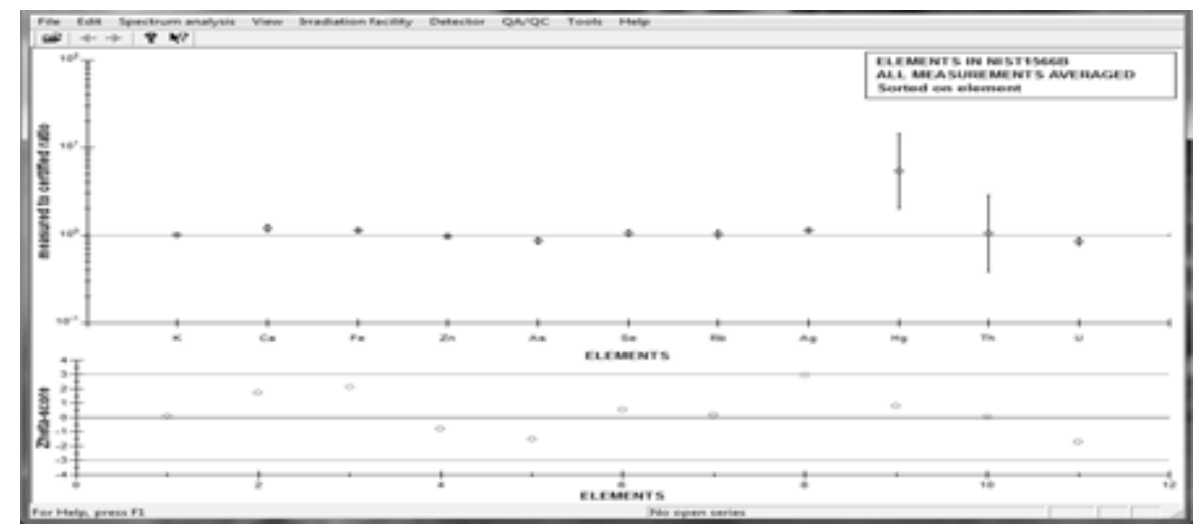

Gambar 2. Pengendalian mutu internal menggunakan NIST SRM 1566b Oyster tissue

Hasil penqendalian mutu penquijan ditam pilkan pada Gambar 2. Dari gambar dapat diketahui rasio nilai hasil analisis unsur-unsur dibandinakan denaan nilai konsentrasi vana ada dalam sertikat. Hasil penauiian valid apabila nilai hasil penquiian sama denqan atau ham ir sama denqan nilai sertifikat, atau rasio $\approx 1$ dan nilai zada dalam kisaran zetha-score \pm 3 . Unsur-unsur $\mathrm{K}, \mathrm{Ca}, \mathrm{Fe}, \mathrm{Zn}, \mathrm{As}, \mathrm{Se}, \mathrm{Rb}$, Th dan U masuk dalam kriteria tersebut. Untuk Ag, nilai rasio cukup bagus mendekati satu yang berarti akurasi bagus tetapi nilai zetha ada di garis level 
atas vanq berarti presisi tidak baqus, hal ini kemungkinan disebabkan karena waktu pencacahan kurang lama sehingqa nilai ketidakpastian perhitungan cukup besar. Sedangkan $\mathrm{Hg}$ presisi data cukup bagus tetapi akurasi kurang bagus, kemungkinan karena adanya interferensi dari selenium.

Pada Tabel 2 ditam pilkan kandungan air dalam daqing ikan, data ini akan diqunakan untuk perhitungan kandunaan mineral di dalam daging ikan basis basah (biasa dikonsumsi). Kandungan air dalam daging ikan memiliki kisaran $75-83 \%$.

Tabel 2. Kandungan air dalam daging ikan diamati.

\begin{tabular}{lc}
\hline Nama lkan & Kandungan air (\%) \\
\hline Tengiri, Authis thazard & 82,92 \\
Tongkol, Acanthocybium solandri & 75,51 \\
Kembung, Rastrelligerfaughni & 78,62 \\
Nila, Oreochromis niloticus & 83,35 \\
Mas, Cyprinus carpio & 82,13 \\
Bawal, Colossoma macropomum & 81,79 \\
\hline
\end{tabular}

Hasil analisis mineral di dalam cuplikan ikan ditampilkan pada Tabel 3. Analisis dilakukan denqan penaulanaan 3 kali dan bada tabel disaiikan nilai rerata konsentrasi mineral dan standar deviasinva denaan basis kering. Mineral hasil analisis terdiri atas mineral esensial vang dibutuhkan tubuh dalam jumlah makro (seperti K, $\mathrm{Na}, \mathrm{Cl}, \mathrm{Ma}$ ) maupun mikro (seperti $\mathrm{Zn}, \mathrm{Fe}, \mathrm{Cr}$, Se) dan unsur toksik vaitu unsur esensial vanq dibutuhkan dalam jumlah kecil dan bersifat toksik apabila berlebih seperti $\mathrm{Cr}$ dan Se, serta unsur yang sama sekali tidak dibutuhkan tubuh karena bersifat toksik seperti As dan $\mathrm{Hg}$.

Konsentrasi unsur toksik As dalam ke tiaa ienis ikan laut memiliki kisaran 3.26 - $3.46 \mathrm{ma} / \mathrm{ka}$. Konsentrasi ini jauh lebih tinqqi apabila dibandingkan denqan konsentrasi As dalam ikan air tawar dari kolam, vang memiliki kisaran konsentrasi $0,76-1,02 \mathrm{mg} / \mathrm{kq}$. Tinqqinva As di dalam ikan laut ini kemunqkinan bersumber dari keberadaan polutan As dalam air laut tempatikan hidup. Sebenarnva kondisi ini bisa diqunakan sebaqai indikator tentang kualitas perairan tersebut. Tetapi vang meniadi permasalahan bahwa ikan hidup berqerak, sehinqqa dalam penelitian ini tidak bisa disimpulkan bahwa perairan tertentu sudah tercemar, karena pencuplikan ikan dilakukan di pasar sehingga tidak diketahui secara spesifik dimana nelayan mengambil ikan tersebut.

Tabel 3. Konsentrasi unsur esensial dan toksik dalam daging ikan basis kering $(\mathrm{mg} / \mathrm{kg})$

\begin{tabular}{|c|c|c|c|c|c|c|c|c|c|c|c|c|}
\hline \multirow{2}{*}{ Unsur } & \multicolumn{2}{|c|}{ Tengiri } & \multicolumn{2}{|c|}{ Kembung } & \multicolumn{2}{|c|}{ Tongkol } & \multicolumn{2}{|c|}{ Nila } & \multicolumn{2}{|c|}{ Mas } & \multicolumn{2}{|c|}{ Bawal } \\
\hline & Rerata & SD & Rerata & SD & Rerata & $\mathrm{SD}$ & Rerata & SD & Rerata & SD & Rerata & SD \\
\hline As & 3,26 & 1,25 & 3,46 & 0,41 & 3,34 & 0,45 & 0,76 & 0,05 & 0,85 & 0,05 & 1,02 & 0,21 \\
\hline $\mathrm{Br}$ & 30,31 & 4,17 & 34,57 & 5,58 & 13,17 & 1,30 & 3,65 & 1,22 & 6,08 & 1,60 & 2,87 & 0,34 \\
\hline $\mathrm{Ca}$ & 4283 & 803 & 3251 & 707,61 & 1720 & 529 & 1813 & 896 & 1681 & 448 & 1643 & 100 \\
\hline $\mathrm{Cl}$ & 6941 & 720 & 2352 & 253 & 2694 & 127 & 3169 & 720 & 2839 & 377 & 2142 & 32,10 \\
\hline Co & 0,33 & 0,03 & 0,32 & 0,06 & 0,38 & 0,15 & 0,35 & 0,08 & 0,35 & 0,01 & 0,29 & 0,06 \\
\hline $\mathrm{Cr}$ & 9,52 & 1,41 & 7,19 & 2,55 & 7,70 & 1,71 & 8,40 & 1,12 & 9,12 & 1,53 & 6,45 & 0,26 \\
\hline $\mathrm{Fe}$ & 145,56 & 15,43 & 63,70 & 15,78 & 74,88 & 8,90 & 63,85 & 4,53 & 73,68 & 1,75 & 59,15 & 7,23 \\
\hline $\mathrm{Hg}$ & 0,31 & 0,04 & 0,48 & 0,05 & 0,11 & 0,04 & 0,17 & 0,09 & 0,36 & 0,25 & 0,26 & 0,13 \\
\hline K & 10666 & 1007 & 17107 & 1931 & 7758 & 409 & 15973 & 1760 & 10240 & 683 & 13935 & 2187 \\
\hline La & 0,84 & 0,19 & 0,60 & 0,41 & 0,81 & 0,15 & 0,48 & 0,39 & 0,44 & 0,25 & 0,31 & 0,29 \\
\hline $\mathrm{Mg}$ & 2217 & 374 & 1508 & 788 & 2066 & 498 & 2024 & 136 & 1985 & 486 & 1768 & 191 \\
\hline $\mathrm{Na}$ & 4172 & 282 & 1627 & 107 & 1793 & 178 & 2292 & 210 & 2541 & 215 & 1417 & 200 \\
\hline $\mathrm{Rb}$ & 3,30 & 0,42 & 4,18 & 0,79 & 1,91 & 0,45 & 1,19 & 0,22 & 0,81 & 0,12 & 0,82 & 0,08 \\
\hline $\mathrm{Se}$ & 5,16 & 0,58 & 4,85 & 0,63 & 3,28 & 0,62 & 1,19 & 0,22 & 0,81 & 0,12 & 0,82 & 0,08 \\
\hline $\mathrm{Zn}$ & 28,83 & 2,86 & 23,98 & 2,26 & 37,34 & 2,46 & 39,30 & 2,95 & 31,22 & 2,33 & 34,71 & 1,18 \\
\hline
\end{tabular}


Arsen dalam ikan air tawar dapat bersumber dari pakan ikan yang berasal dari tepung ikan yang mengandung logam berat termasuk As. Logam berat ini diduga berasal dari kontaminasi pada saat proses pembuatan tepung $i k a n^{(9)}$. Konsentrasi Ca dalam ikan laut (tengiri dan kembung) lebih tinggi dari ke empat jenis ikan lainnya, demikian juga dengan konsentrasi $\mathrm{Rb}$. Konsentrasi Br dalam ikan lautmemiliki kisaran 13,17 - 34,57 $\mathrm{mg} / \mathrm{kg}$, konsentrasi ini jauh lebih tinggi dari pada di dalam ikan air tawar 2,87 - 6,08 mg/kg. Demikian juga dengan selenium, konsentrasi dalam ikan lautjauh lebih tinggi 3,28 - 5,16 dibandingkan dalam ikan air tawar 0,81 - 1,19 $\mathrm{ma} / \mathrm{kg}$. Jenis unsur lainnva memiliki konsentrasi bervariasi tergantuna ienis ikannva. Selenium merupakan unsur penting dari enzym vang berperan dalam membuat antioksidan, kekurangan selenium menimbulkan geiala pertumbuhan lambat; $d v s t r o p h v$ otot dan necrosis iantung, ginial dan hati. Baqi daerah atau negara vang tingkat kandungan selenium dalam tanahnya rendah seperti Australia, maka mengkonsumsi ikan laut menjadi faktor yang amat penting untuk mencegah kekurangan selenium.

Pada Tabel 4 ditampilkan konsentrasi mineral di dalam cuplikan daqing ikan basis basah vang diqunakan untuk menghitung perkiraan asupan mineral diterima konsumen dari menqkonsumsi ikan. Nilai ini diperoleh dengan mengkoreksi berat ikan basis kering terhadap kandungan airnya yang tertera dalam Tabel 2 .

Tabel 4. Konsentrasi unsur esensial dan toksik dalam daging ikan basis basah $(\mathrm{mg} / \mathrm{kg})$

\begin{tabular}{ccccccc}
\hline Unsur & Tengiri & Kembung & Tongkol & Nila & Mas & Bawal \\
\hline $\mathrm{As}$ & 0,56 & 0,74 & 0,82 & 0,13 & 0,15 & 0,19 \\
$\mathrm{Br}$ & 5,18 & 7,39 & 3,23 & 0,61 & 1,09 & 0,52 \\
$\mathrm{Ca}$ & 732 & 695 & 422 & 302 & 300 & 299 \\
$\mathrm{Cl}$ & 1185 & 503 & 660 & 528 & 507 & 390 \\
$\mathrm{Co}$ & 0,06 & 0,07 & 0,09 & 0,06 & 0,06 & 0,05 \\
$\mathrm{Cr}$ & 1,63 & 1,54 & 1,89 & 1,40 & 1,63 & 1,17 \\
$\mathrm{Fe}$ & 24,86 & 13,61 & 18,35 & 10,64 & 13,16 & 10,77 \\
$\mathrm{Hg}$ & 0,05 & 0,10 & 0,03 & 0,03 & 0,06 & 0,05 \\
$\mathrm{~K}$ & 1822 & 3655 & 1901 & 2662 & 1828 & 2538 \\
$\mathrm{La}$ & 0,14 & 0,13 & 0,20 & 0,08 & 0,08 & 0,06 \\
$\mathrm{Mg}$ & 379 & 322 & 506 & 337 & 354 & 322 \\
$\mathrm{Na}$ & 712 & 348 & 439 & 382 & 458 & 258 \\
$\mathrm{Rb}$ & 0,56 & 0,89 & 0,47 & 0,20 & 0,14 & 0,15 \\
$\mathrm{Se}$ & 0,88 & 1,04 & 0,80 & 0,20 & 0,14 & 0,15 \\
$\mathrm{Zn}$ & 4,92 & 5,12 & 9,15 & 6,55 & 5,58 & 6,32 \\
\hline
\end{tabular}

Berdasarkan Peraturan Kepala Badan Pengawasan Obat dan Makanan RI No. HK.00.06.1.52.4011 tahun 2009, batas maksimum cemaran logam berat dalam makanan sebagai berikut: untuk arsen batas maksimum di dalam ikan olahan $1,0 \mathrm{mg} / \mathrm{kg}$, untuk merkuri, batas maksimum di dalam ikan olahan $0,5 \mathrm{mg} / \mathrm{kg}$ dan di dalam ikan predator olahan (seperti cucut, tuna, merlin dsb) 1,0 mg/kg. Untuk unsur lainya seperti $\mathrm{Cr}, \mathrm{Fe}, \mathrm{Zn}$ dan Se tidak diatur dalam peraturan ini. Dengan mengacu nilai tersebut maka kandungan arsen dan merkuri di dalam cuplikan ikan diteliti, ada di bawah baku mutu.

Untuk mengetahui asupan mineral yang diterima konsumen dari mengkonsumsi ikan, maka dengan mengambil data tingkat konsumsi ikan masyarakat Indonesia tahun 2011 sebesar 31,64 kg/kapita/tahun, dapat dihitung asupan harian atau daily intake (DI) mineral esensial maupun toksik yang berasal dari konsumsi ikan, dengan hasil seperti tertera dalam Tabel 5 .

Tabel 5. Evaluasi asupan mineral (mg/hari)

\begin{tabular}{ccccccc}
\hline Unsur & Tengiri & Kembung & Tongkol & Nila & Mas & Bawal \\
\hline $\mathrm{As}$ & 0,05 & 0,06 & 0,07 & 0,01 & 0,01 & 0,02 \\
$\mathrm{Br}$ & 0,45 & 0,64 & 0,28 & 0,05 & 0,09 & 0,05 \\
$\mathrm{Ca}$ & 63,41 & 60,21 & 36,54 & 26,19 & 26,02 & 25,94 \\
$\mathrm{Cl}$ & 102,76 & 43,56 & 57,23 & 45,78 & 43,94 & 33,82 \\
$\mathrm{Co}$ & 0,00 & 0,01 & 0,01 & 0,01 & 0,01 & 0,00 \\
$\mathrm{Cr}$ & 0,14 & 0,13 & 0,16 & 0,12 & 0,14 & 0,10 \\
\hline
\end{tabular}




\begin{tabular}{ccccccc}
\hline $\mathrm{Fe}$ & 2,15 & 1,18 & 1,59 & 0,92 & 1,14 & 0,93 \\
$\mathrm{Hg}$ & 0,00 & 0,01 & 0,00 & 0,00 & 0,01 & 0,00 \\
$\mathrm{~K}$ & 157,90 & 316,85 & 164,82 & 230,76 & 158,50 & 220,02 \\
$\mathrm{La}$ & 0,01 & 0,01 & 0,02 & 0,01 & 0,01 & 0,00 \\
$\mathrm{Mg}$ & 32,82 & 27,93 & 43,89 & 29,24 & 30,72 & 27,91 \\
$\mathrm{Na}$ & 61,76 & 30,13 & 38,09 & 33,11 & 39,33 & 22,37 \\
$\mathrm{Rb}$ & 0,05 & 0,08 & 0,04 & 0,02 & 0,01 & 0,01 \\
$\mathrm{Se}$ & 0,08 & 0,09 & 0,07 & 0,02 & 0,01 & 0,01 \\
$\mathrm{Zn}$ & 0,43 & 0,44 & 0,79 & 0,57 & 0,48 & 0,55 \\
\hline
\end{tabular}

Untuk evaluasi kecukupan asupan mineral dari konsumsi ikan, maka pada Tabel 6, ditampilkan data acuan menurut Institute of Medicine USA. Pada tabel ini sebagai contoh diambil data acuan kebutuhan nutrisi untuk laki-laki dewasa usia 19 - 30 tahun.

Tabel 6. Data acuan diqunakan untuk studi kebutuhan nutrisi bagi laki-laki, usia 19-30 tahun menurut Institute of Madicine, USA[10]

\begin{tabular}{ccccc}
\hline Unsur & EAR & RDAAl & UL & Satuan \\
\hline As & $\mathrm{NE}$ & $\mathrm{ND}$ & $\mathrm{ND}$ & $\mu \mathrm{g}$ \\
$\mathrm{Ca}$ & 800 & 1000 & 2500 & $\mathrm{mg}$ \\
$\mathrm{Cl}$ & $\mathrm{NE}$ & 2300 & 3600 & $\mathrm{mg}$ \\
$\mathrm{Cr}$ & $\mathrm{ND}$ & 35 & $\mathrm{ND}$ & $\mu \mathrm{g}$ \\
$\mathrm{Fe}$ & 6 & 8 & 45 & $\mathrm{mg}$ \\
$\mathrm{Mg}$ & 330 & 400 & 350 & $\mathrm{mg}$ \\
$\mathrm{Na}$ & $\mathrm{NE}$ & 1500 & 2300 & $\mathrm{mg}$ \\
$\mathrm{Se}$ & 45 & 55 & 400 & $\mu \mathrm{gg}$ \\
$\mathrm{K}$ & $\mathrm{NE}$ & 4700 & $\mathrm{NE}$ & $\mathrm{mg}$ \\
$\mathrm{Zn}$ & 9,4 & 11 & 40 & $\mathrm{mg}$
\end{tabular}

*) EAR (Estimated Average Requirement), RDA(Recommended Dietary Allowence), Al (Adequate Intake), UL (Tolerable UpperIntake Levels), $\mathrm{NE}$ (Not Estimated), ND (Not Determined),

Estimated Average Requirement (EAR) adalah rata-rata asupan nutrisi harian yang akan memenuhi kebutuhan giz setengah individu dalam satu kelompok, Recommended Dietary Allowence (RDA) adalah distribusi dimana asupan memadai untuk 97 - 98\% dari kelompok populasi untuk berbagai kelompok usia dan jenis kelamin, RDA ini digunakan sebagai tingkat asupan yang direkomendasikan untuk semua individu, Adequate Intake (Al) digunakan apabila nilai RDA belum ditetapkan, Upper Intake Level (UL) merupakan tingkat maksimum total harian kronis asupan nutrisi yang dinilai tidak menimbulkan resiko kesehatan ${ }^{(11) .}$

Arsen bersifat toksik bagi tubuh, dan nilai RDAnya tidak ditetapkan. Dari Tabel 5 , dapat diketahui dengan mengkonsumsi ikan sebesar 86,68 gr/hari, maka asupan arsen berkisar 0,01-0,07 mg/hari, sedangkan mineral lainnya seperti kalsium $=2,5-6,3 \% ; \mathrm{Cl}=1,5-4,4 \% ; \mathrm{Fe}=11,5-26,9 \% ; \mathrm{Na}=1,5-4,1 \% ; \mathrm{K}=3,4-6,7 \%$ dan $\mathrm{Zn}=$ $3,9-7,2 \%$ tercukupi dari asupan nutrisi yang direkomendasikan. Kromium sudah melebihi dari nilai yang direkomendasikan $35 \mu \mathrm{g} / \mathrm{hari}$, yaitu 100 - $160 \mu \mathrm{g} / \mathrm{hari}$. Sedangkan asupan mineral selenium 10 - $80 \mu \mathrm{g} / \mathrm{hari}$, dan nilai direkomendasikan adalah $55 \mu \mathrm{g} / \mathrm{hari}$, jadi ikan merupakan salah satu jenis bahan makanan sumber selenium.

Dari studi yang dilakukan maka dapat diketahui bahwa ikan merupakan sumber protein hewani yang menggandung mineral yang sangat dibutuhkan oleh tubuh untuk pertumbuhan, tetapi juga mengandung unsur toksik yang tidak dibutuhkan oleh tubuh. Informasi data tersebut sangat penting berkaitan dengan keamanan pangan, sehingga konsumen dapat mengatur diet yang dikonsumsi. 


\section{KESIMPULAN}

Dari penelitian dapat disimpulkan bahwa ikan mengandung unsur mineral yang bersifat esensial $\mathrm{Ca}, \mathrm{Cl}$, $\mathrm{Co}, \mathrm{Fe}, \mathrm{K}, \mathrm{Mg}$, Na, Se dan Zn dan toksik( $\mathrm{Cr}, \mathrm{As}$, Hg). Kadar arsen di dalam ikan laut 0,56 - $02 \mathrm{mg} / \mathrm{kg}$, nilai ini lebih tinggi dibandingkan konsentrasi dalam ikan air tawar 0,13 $-0,19 \mathrm{mg} / \mathrm{kg}$. Semua jenis ikan diteliti mengandung merkuri antara $0,03-0,1 \mathrm{mg} / \mathrm{kg}$. Nilai tersebut masih di bawah nilai baku mutu menurut BPOM. Ikan merupakan bahan makanan sumber mineral yang dibutuhkan tubuh, sehingga dengan mengkonsumsi ikan sebagian kebutuhan mineral terpenuhi. Adanya logam toksik Hg dan As dalam ikan yang tidak direkomendasikan ada di dalam diet, maka monitoring keamanan pangan khususnya ikan perlu rutin dilakukan.

\section{UCAPAN TERIMAKASIH}

Ucapan terimakasih disampaikan kepada Rohani, mahasiswi Fakultas Farmasi Untag-Jakarta, yang telah membantu dalam sampling.

\section{DAFTAR PUSTAKA}

1. www, wpi,kkp,go,id, Ikan Penyuplai Protein, diunduh 10 Desember (2012).

2. LESTARI dan EDWARD, Dampak Pencemaran Logam Berat terhadap Kualitas air laut dan sumberdaya perikanan (Studi Kasus kematian masal ikan-iakn di Teluk Jakarta), Makara, Sains, 8 (2) (2004)52-58

3. SIREGAR Y.I, ZAMRI A, PUTRA H, Penyerapan Pb pada Sistim Organ Ikan Mas (Cyprianus Carpio L), Jurnal Ilmu Lingkungan, 6 (2012)

4. PURNOMO T, MUCHYIDDIN, Analisis Kandungan Timbal $(\mathrm{Pb})$ pada ikan bandeng (Chanos chanos Forsk) di Tambak Kecamatan Gresik, Majalah IImiah Kelautan Neptunus, 14(1) (2007) 68-77.

5. PRIYANTO N, DWIYANTO dan ARIYANI F, Kandungan Logam Berat ( $\mathrm{Hg}, \mathrm{Pb}, \mathrm{Cd}$, dan $\mathrm{Cu})$ Pada ikan, air dan sedimen di Waduk Cirata Jawa Barat, Jurnal Pascapanen dan Bioteknologi Kelautan dan Perikanan, $3(1)(2008)$

6. YUDO S, Kondisi Pencemaran Logam Berat di Perairan Sungai DKI Jakarta, JAl, 2(1)(2006).

7. ANONIM, data Susenas 2008 yang sudah diolah, http://www,wpi,kkp,go,id/wpcontent/uploads/2010/05/tingkat-konsumsi-dan-serapan-pasar1,jpg, diunduh 10 Desember (2012)

8. IAEA-TECDOC-564, Practical Aspects af Operating a neutron activation Analysis Laboratory, A Technical Document Issued by the International Atomic Energy Agency, Viena (1990)

9. PRATIWI, ROST IKAR, DHAHIYAT Y, Pengaruh TingkatPemberian Pakan Terhadap Laju Pertumbuhan dan deposisi LB pada ikan nilem di karamba jaring apung Waduk Ir. H Djuanda, Jurnal Akuatika 2 (2)(2011) ISSN 0853-2523.

10. ANONIM, Dietary Reference Intakes (DRIs): Estimated Average Requirements,

11. Food and Nutrition Board, Institute of Medicine, National Academies, http://www.iom.edu_activities_nutrition_summary, diunduh 4 Februari (2013).

12. RENWICK A.G, FLYN A, FLETCHERR.J, MULLER D.J.G, TUIJTELAARS S, VERHAGEN H, Risk-benefit analysis of micronutrients, Food and Chemical Toxicology 42(2004) 1903-1922. 